\title{
KEDUDUKAN AHLI WARIS PENGGANTI DAN PRINSIP KEADILAN DALAM HUKUM WARIS ISLAM
}

\author{
Sofyan Mei Utama \\ Sekolah Tinggi Hukum Bandung \\ E-mail: Sofyan.meiutama@yahoo.com
}

\begin{abstract}
Legality of a substitute beneficiary obtains a guarantee in article 185 of Islamic Law Compilation, and it is in accordance with justice principle in inheritance, and inheritant policy in dividing inheritance to a substitute beneficiary, and it is called pre-empitiv, in his or her life (inheritant's life) divided his or her property to a beneficiary or substitute beneficiary. This kind of property division does not distinguish a gender among beneficiaries or substitute beneficiaries with the purpose of mutual welfare and benefits among brothers or sisters, the same as the purpose of islamic law (maqashid al-syari'ah) for people's welfare and benefits, one of them is the theory on Al-Maslahah Al-Mursalah which is required to be more careful, avoiding carnality.
\end{abstract}

Keywords: beneficiary; substitute beneficiary; inheritant; islamic law.

\begin{abstract}
Abstrak
Legalitas ahli waris pengganti mendapat jaminan dalam Pasal 185 Kompilasi Hukum Islam (KHI), hal itu sesuai dengan prinsip keadilan dalam warisan, dan suatu kebijakan pewaris dalam pembagian warisan untuk ahli waris pengganti, yang disebut dengan kebijaksanaan pre-empitiv yaitu, pada masa hidup pewaris dengan membagikan hartanya pada ahli waris atau ahli waris penganti. Pembagian tersebut tanpa membedakan jenis kelamin, di antara ahli waris atau ahli waris penganti, dengan maksud untuk kemaslahatan dalam hidup bersaudara. Seperti halnya dengan tujuan hukum Islam (maqashid al-syari'ah) yang ditujukan untuk kemaslahatan ummat. Salah satunya teori mengenai Al-Maslahah Al-Mursalah yang diperlukan untuk kehati-hatian, menghindari mengikuti hawa nafsu belaka.
\end{abstract}

Kata Kunci: Ahli Waris, Ahli Waris Pengganti. 


\section{A. PENDAHULUAN}

Ahli waris pengganti disebutkan dalam Pasal 185 Kompilasi Hukum Islam (KHI) Inspres nomor 1 Tahun 1991, merupakan hasil ijtihad para mujtahid Indonesia yaitu Keputusan bersama tanggal 21 Maret 1985 Ketua Mahkamah Agung dan Menteri Agama Republik Indonesia yang membentuk panitia untuk mengumpulkan bahan-bahan dan merancang Kompilasi hukum Islam menyangkut hukum Perkawinan, Kewarisan dan Perwakafan untuk selanjutnya akan dipergunakan oleh Pengadilan Agama dalam melaksanakan tugas dan wewenangnya. ${ }^{1}$

Hakikat Inpres tersebut merupakan aplikasi dari surat (QS:4:59) ${ }^{2}$ menyatakan mengenai sumber hukum Islam terdiri dari kitabullah, As-Sunnah, dan Ijtihad.

Ayat inipun merupakan dasar hukum Islam lahirnya teori penaatan hukum ${ }^{3}$, bagi umat Islam wajib taatkepadaAllah SWT dan Rasulullah Saw, serta mengikuti peraturan yang dibuat negara. Menurut Ichtijanto, bahwa taat kepada Allah SWT dan taat kepada Rasul-Nya menggambarkan taat kepada syari'at Islam dan mengikuti ulil amri adalah menggambarkan ketaatan seoarang muslim kepada ijtihad yang dilakukan ulil amri untuk menjawab tantangan kebutuhan Karena perubahan dan perkembangan. ${ }^{4}$
Asal kata"Waris" asal kata perkataan waris berasal dari kata bahasa Arab yaitu "waris" secara gramatikal berarti "yang tinggal" maka dengan demikian apabila dihubungkan dengan persoalan hukum waris, perkataan waris tersebut berarti orang-orang yang berhak untuk menerima pusaka dari harta yang ditinggalkan oleh si mati, dan populer diistilahkan dengan "ahli waris."5 Dan dasar pokok hukum waris Islam terdapat di dalam (Q:4 : 7) disebutkan sebagai berikut:

"Bagi orang laki-laki ada hak bagian dari harta peninggalan ibu bapak dan kerabatnya, dan bagi orang perempuan ada hak bagian (pula) dari harta peninggalan ibu bapak dan kerabatnya, baik sedikit ataupun banyak menurut bagian yang telah ditetapkan".

Ayat di atas merupakan aturan yang mengatur tentang adanya hak bagi para ahli waris baik pria dan wanita atas pembagian harta peninggalan pewaris yang wafat, berdasarkan ketetapan Allah SWT. ${ }^{6}$ Mengenai masalah peninggalan si pewaris yang berupa harta bendanya atau miliknya maka, dapat diwariskan kepada ahli warisnya sesuai dengan ketentuanketentuan yang berlaku. $^{7}$

Terjadinya waris mewaris dalam hukum kewarisan Islam, ada tiga sebab

Abdurrahman, Kompilasi Hukum Islam di Indonesia, Akademika Pressindo, Jakarta, 1992, hlm. 18.

Al-Qur'an surat An-Nisa: 59.

Teori penaatan hukum ini dikemukakan Ichtiyanto dalam Juhaya, Hukum Islam di Indonesia, PT. Remaja Rosdakarya, Bandung, 1991, hlm. 102. Lihat juga tulisan Sofyan mengenai "Pengembangan Hukum Waris Islam di Indonesia”, dalam Jurnal “Wawasan Hukum” Volume 25 No. 2 September 2011.

4 Ichtijanto dalam Juhaya S. Praja, Hukum Islam di Indonesia, Perkembangan dan Pembentukan, PT. Remaja Rosdakarya, Bandung, 1991, hlm. 103.

5 Suhrawardi dan Komis Simanjuntak, Hukum Waris Islam, Sinar Grafika, Jakarta, 2000, hlm. 52.

6 M. Ali Hasan, Hukum Warisan Dalam Islam, Bulan Bintang, Jakarta, 1990, hlm. 32.

7 Ibid., hlm. 35. 
mewaris, yaitu (a) karena perkawinan; (b) hubungan kekerabatan; (c) karena wala atau "perwalian" kekerabatan yang timbul membebaskan perbudakan, ${ }^{8}$ Karena perkawinan yang sah menimbulkan hubungan kewarisan, jika seorang suami meninggal dunia, maka istrinya atau jandanya mewarisi harta suaminya, demikian juga jika seorang istri meninggal dunia, maka suaminya mewarisi harta istrinya. Yang dimaksud dengan hubungan kekerabatan di sini adalah hubungan famili, hubungan kekerabatan ini menimbulkan hak waris jika salah satu meninggal dunia. Misalnya, antara anak dengan orang tuanya.

"Wala" yaitu hubungan hukmiah, suatu hubungan yang ditetapkan oleh hukum Islam, ${ }^{9}$ karena majikan/tuannya telah memberikan kenikmatan untuk hidup merdeka dan mengembalikan hak asasi kemanusiaan kepada budaknya, tegasnya jika seorang tuan memerdekakan budaknya, maka terjadilah hubungan keluarga yang disebut wala'ul 'itqi, dengan adanya hubungan tersebut seorang menjadi ahli waris dari budak yang dimerdekakannya itu, dengan syarat budak yang bersangkutan tidak mempunyai ahli waris sama sekali, baik karena hubungan kekerabatan maupun perkawinan, akan tetapi masa kini "wala" di Indonesia tidak ada. ${ }^{10}$ Menyangkut kedudukan ahli waris pengganti mengandung sifat prinsip keadilan dalam hukum Islam, yang diantaranya meliputi berbagai aspek kehidupan, ${ }^{11}$ termasuk dalam hukum keluarga dan waris, Allah SWT memerintahkan manusia untuk berlaku adil dalam segala hal, perintah adil berlaku bagi setiap orang tanpa pandang bulu, termasuk dalam pembagian waris. Dalam warisan Islam mengalami perkembangan pembentukan hukum waris sebagaimana dikemukakan Munawir Sjadzali, makin meningkatnya semangat kembali kepada agama di kalangan masyarakat Islam di Indonesia, tetapi harus diakui masih cukup banyaknya sikap "mendua" dalam penaatan hukum Islam, artinya belum konsekuen. ${ }^{12}$

Dari segi prinsip keadilan dapat dilihat pendapat Munawir yang menyebutkan bahwa, banyak keluarga yang mengambil kebijaksanaan-kebijaksanaan pre-empitiv, (mendahului) pada masa hidup membagibagikan sebagian besar dari kekayaan kepada anak-anaknya dengan bagian

8 Toto Suryana, dkk, Pendidikan Agama Islam Untuk Perguruan Tinggi, Tiga Mutiara, Bandung, hlm. 144.

9 Muhammad Ali as-Shabana, Hukum Waris Dalam Syariat Islam, CV. Dipenegoro, Bandung, 1988, hlm. 47.

10 Kompilasi Hukum Islam, Pasal 171 Bab 1 Maksud hukum kewarisan adalah, hukum yang mengatur tentang pemindahan hak pemilikan harta peninggalan (tirkah) pewaris, menentukan siapa-siapa yang berhak yang menjadi ahli waris dan berapa bagiannya masing-masing, kemudian, pewaris adalah orang yang pada saat meninggalnya atau yang dinyatakan meninggal berdasarkan keputusan pengadilan beragama Islam, meninggalkan ahli waris dan harta peninggalan ahli waris, orang yang pada saat meninggal dunia mempunyai hubungan darah atau hubungan perkawinan dengan pewaris beragama Islam dan tidak terhalang karena hukum untuk menjadi ahli waris, harta peninggalan adalah harta yang ditinggalkan oleh pewaris baik berupa harta benda yang menjadi miliknya maupun hak-haknya.

11 Juhaya S. Praja, Filsafat Hukum Islam, PT. Lathifah Press, Fakultas Syari'ah IAILM Suryalaya, Tasikmalaya, 2004, hlm. 72.

12 Munawir Sjadzali, Mantan Menteri Agama Republik Indonesia, dalam Kabinet pembangunan Tahun 1983-1988, 1988-1993, Reaktulisasi Ajaran Islam, artikel, hlm. 83. 
sama besarnya tanpa membedakan jenis kelamin, sebagai hibah, atau di Kalimantan Selatan lebih dikenal dengan "wasiat wajib" dengan demikian pada waktu pewaris meninggal, kekayaan tinggal sedikit atau hampir habis, dalam kasus tersebut memang tidak terjadi penyimpangan, namun apakah penaatan hukum Islam atau melaksanakan ajaran agama dengan semangat seperti itu sudah betul? ${ }^{13}$

Terjadinya penyimpangan dari faraaid tersebut tidak selalu disebabkan oleh tipisnya keyakinan terhadap agama tetapi dapat juga disebabkan oleh pertimbangan untuk kebaikan dikemudian hari, tetapi diharapkan dapat memenuhi prinsip keadilan dalam hukum Islam, yang membawa kebaikan dunia akhirat. Dari uraian tersebut terdapat beberapa permasalahan untuk dapat diteliti seperti adanya ahli waris pengganti dalam hukum waris Islam, apakah ada hubungan kedudukan ahli waris dengan prinsip keadilan dalam hukum Islam, baik dari segi prinsip keadilannya maupun dari hukumnya.

Adapun identifikasi masalahnya adalah: Apa yang melandasi kedudukan ahli waris pengganti dalam hukum Islam dan bagaimana hubungannya dengan teori Maslahah Mursalah dalam hukum Islam.
B. PEMBAHASAN

\section{Landasan Hukum Ahli Waris Pengganti}

Landasan hukum Ahli Waris Pengganti tidak lepas dari pokok-pokok permasalahan yaitu mengenai hukum ahli waris pengganti dan untuk sampai pada kedudukan ahli waris pengganti perlu melihat mengenai hukum waris yang ada dan berlaku di Indonesia sampai saat ini masih merupakan unifikasi hukum. Atas dasar hukum waris yang masih pluralistik, akibatnya sampai sekarang ini pengaturan warisan di Indonesia masih belum terdapat keseragaman. ${ }^{14}$ Bentuk sistem hukum waris sangat erat kaitannya dengan bentuk masyarakat dan sifat kekeluargaan, sedangkan sistem kekeluargaan pada masyarakat Indonesia berpokok pangkal pada sistem menarik garis keturunan. Berkaitan dengan hal ini seperti diketahui di Indonesia secara umum setidaknya dikenal tiga macam sistem hukum keturunan, ${ }^{15}$ yaitu: Sistem Patrilineal/sifat kebapakaan, ${ }^{16}$ Sistem Matrilineal/sifat keibuan, Sistem Bilateral atau parental/sifat kebapakibuan, ${ }^{17}$ Pluralistiknya hukum waris di Indonesia disebabkan oleh adat istiadat masyarakat Indonesia yang bervariatif, serta dilengkapi oleh sistem hukum waris Islam, yang bersumber pada Al-Qur'an, As-Sunnah. Dan Ijtihad. Sistem hukum ini

\footnotetext{
13 Ibid.

14 Eman Suparman, Hukum Waris Indonesia, Dalam Perspektif Islam, Adat, dan BW, Refika Aditama, Bandung, 2007, hlm. 5.

15 M. Idris Ramulyo, "Suatu Perbandingan Antara Ajaran Syafi'i dan Wasiat Wajib di Mesir, Tentang Pembagian Harta Warisan Untuk Cucu Menurut Islam” Majalah Hukum Dan Pembangunan No. 2 Thn. XII Maret 1982, Jakarta FHUI, 1982, hlm. 154.

16 Wirjono Prodjodikoro, Op.Cit., hlm. 10.

17 Ibid., hlm. 10.
} 
cukup dominan pada masyarakat muslim di Indonesia. Kemudian hukum waris barat peninggalan zaman Hindia Belanda yang bersumber pada BW/Burgerlijk Wetboek.

Hukum waris sebagai salah satu bidang hukum yang berada di luar bidang yang bersifat sulit untuk diperbaharui dengan jalan perundang-undangan atau kodifikasi guna mencapai suatu unifikasi hukum. Hal itu disebabkan upaya ke arah membuat hukum waris yang sesuai dengan kebutuhan dan kesadaran masyarakat akan senantiasa mendapat kesulitan, mengingat beraneka ragam corak budaya, agama, sosial, dan adat istiadat serta sistem kekeluargaan yang hidup dan berkembang di dalam masyarakat Indonesia. ${ }^{18}$ Karenanya hukum waris yang berlaku di Indonesia tergantung kepada hukumnya si pewaris, artinya "hukum waris mana yang berlaku bagi orang yang meninggal dunia”, maksudnya jika pewaris orang Indonesia, maka yang berlaku hukum warisnya adalah hukum adat, kalau pewaris golongan penduduk Eropa, atau Timur Asing Cina, bagi mereka berlaku hukum waris Barat. ${ }^{19}$

Sedangkan jika pewaris golongan penduduk Indonesia yang beragama Islam biasanya menggunakan hukum waris berdasarkan hukum waris Islam, dan bagi pewaris golongan penduduk Timur Asing lainnya seperti Arab, Pakistan, atau India, maka terhadap mereka berlaku hukum mereka masing-masing. ${ }^{20}$ Menurut Eman Suparman, dari prinsip-prisip hukum waris Indonesia exiting yang pluralistik itulah kiranya dapat dipahami betapa sulitnya upaya untuk menyatukan sistem hukum waris dalam bentuk sistem hukum waris nasional Indonesia yang dicitacitakan (Ius Contituendum)

Hukum waris Islam berdasarkan pada Al-Qur'an yaitu sumber hukum tertinggi, kemudian As-Sunnah sebagai sumber kedua dan hasil-hasil Ijtihad para ahli hukum Islam yang dituangkan dalam suatu kompilasi melalui keputusan pemerintah, seperti Instruksi Presiden Republik Indonesia Nomor 1 Tahun 1991 tentang Kompilasi Hukum Islam. Dalam Al-Qur'an mengenai hukum waris seperti:

a. Bahwa laki-laki dan perempuan ada bagian warisannya ${ }^{21}$

b. Mengenai pembagian waris bagian anak, bagian ibu, dan bapak, serta adanya wasiat dan hutang pewaris. ${ }^{22}$

18 Eman Suparman, Op.Cit., hlm. 8.

19 Retno Sutantio, Wanita dan Hukum, Alumni, Bandung, 1979, hlm. 84.

20 Ibid., hlm. 85.

21 QS An- Nisa(4):7, "Bagi orang laki-laki ada hak bagian dari harta sepanjang ibu-bapak, dan kerabatnya, dan bagi wanita ada pula dari harta peninggalan ibu-bapak, dan kerabatnya, baik sedikit atau banyak menurut bagian yang telah ditetapkan".

22 Ibid., ayat11, "Allah mensyariatkan bagimu tentang (pembagian pusaka) untuk anak-anakmu, yaitu: bagian seorang anak laki-laki sama dengan bagian duaanak perempuan. Dan jika anak itu semua perempuan lebih dari dua, maka bagi mereka dua pertiga dari harta yang ditinggalkan, jika anak perempuan itu seorangs aja, maka ia memperoleh separo harta.Dan untuk dua orang ibu-bapak masingmasing memperoleh seperenam dari harta yang ditinggalkan jika yang meninggal itu mempunyai anak, dan jika yang meninggal tidak mempunyai anak dan ia diwarisi oleh ibu-bapaknya, maka ibunya mendapat sepertiga, jika pewaris mempunyai beberapa saudara, maka ibunya mendapat seperenam (pembagian-pembagian tersebut sesudah dipenuhi wasiat yang ia buat, atau dan sesudah dibayar hutangnya. 
c. Bagian duda dan bagian janda ${ }^{23}$

Wujud warisan atau harta peninggalan menurut hukum Islam berbeda dengan wujud warisan hukum Barat juga hukum waris Adat. Warisan menurut hukum Islam adalah "sejumlah harta benda serta segala hak dari yang meninggal dunia dalam keadaan bersih" artinya harta peninggalan yang diwarisi oleh para ahli waris adalah sejumlah harta benda serta segala hak, "setelah dikurangi dengan pembayaran hutang-hutang pewaris dan pembayaranpembayaran lain yang diakibatkan oleh wafatnya si pewaris". ${ }^{24}$

Menurut Hazairin, bahwa "sistem kewarisan Islam adalah sistem individual bilateral" Al-Qur'an menyebutkan dalam surat An-Nisa ayat: (7), (8), (11), (12), (33), dan (176). Hal ini merupakan ciri atau spesifikasi sistem hukum waris Islam menurut Al-Qur'an. ${ }^{25}$ Pewaris adalah orang yang meninggal dunia, baik laki-laki maupun perempuan yang meninggalkan sejumlah harta benda maupun hak-hak yang diperoleh selama hidupnya, baik dengan surat wasiat, maupun tanpa surat wasiat, dan yang menjadi dasar hal untuk mewaris menurut Al-Qur'an yaitu:

a. Karena hubungan darah

b. Hubungan semenda atau pernikahan

c. Hubungan persaudaraan, karena agama yang ditentukan oleh Al-Qur'an bagiannya tidak lebih dari sepertiga harta pewaris QS. Al-Ahzab: (6)

d. Hubungan kerabat karena hijarah, zaman dulu pada saat permulaaan pengembangan Islam, meskipun tidak ada hubungan darah QS. Al-Anfal: (75). ${ }^{26}$

Sebagaimana diketahui bahwa ahli waris dalam hukum Islam, adalah seseorang atau beberapa orang yang berhak mendapat bagian dari harta peninggalan, secara garis besar golongan ahli waris dapat dibedakan kedalam tiga golongan yaitu:

a. Ahli waris yang sudah ditentukan dalam Al-Qur'an disebut dengan dzul faraa'idh, yaitu ahli waris yang langsung yang mesti selalu mendapat bagian tetap tertentu yang tidak berubah-ubah, hal ini terdapat dalam Al-Qur'an surat An-Nisa: ayat 11, 12, 176 dan Komar Andasasmita, menguraikan jumlah ahli waris berdasarkan Al-Qur'an yang terdiri atas dua belas jenis yaitu:

1) Dalam garis ke bawah:

- anak perempuan

- anak perempuan dari anak laki-laki (QS. IV:11)

2) Dalam garis ke atas:

- ayah

- ibu

- $\quad$ kakek dari garis ayah

23 Ibid., ayat 12 "Dan bagi (suami-suami) seperdua, dari harta yang ditinggalkan isteri-isteri, jika tidak mereka tidak mempunyai anak. Jika isteri-isteri itu mempunyai anak, maka mendapat seperempat, dan harta yang ditinggalkannya, sesudah dipenuhi wasiat, jika mereka buat atau (dan) sesudah dibayar hutangnya.Para isteri memperoleh seperempat harta yang kamu tinggalkan jika kamu tidak mempunyai anak, jika kamu mempnyai anak, makapara isteri mempoleh seperdelapan dari harta yang kamu tinggalkan sesudah dipenuhi wasiat yang kamu buat, atau (dan) sesudah dibayar hutang-hutangmu...”

24 Wirjono Prodjodikoro, Op.Cit., hlm.17

25 Hazairin, Hukum Kewarisan IslamMmenuru Al-Qur'an, Jakarta, TT, hlm. 14.

26 Eman Suparman, Op.Cit., hlm. 16-17. 
- nenek baik dari garis ayah maupun dari garis ibu (QS. IV:11)

3) Dalam garis ke samping:

- saudara perempuan yang seayah dan seibu dari garis ayah

- saudara perempuan tiri (halfzuster) dari garis ayah (QS. IV:176)

- saudara lelaki tiri (halfbroeder) dari garis ibu (QS. IV:12)

- saudara perempuan tiri (halfzuster) dari garis ibu (QS. IV:12)

- duda

- janda (QS. IV:12)

b. Ahli waris yang ditarik dari garis ayah, disebut Ashabah, yang dalam bahasa Arab berarti "anak lelaki atau kaum kerabat dari bapak" Ashabah dalam ajaran kewarian patrilineal Syafi'i adalah golongan ahli waris yang mendapat bagian terbuka atau bagian sisa. Jadi bagian ahli yang terlbih dahlu dikeluarkan adalah dzulfaraidh dan sisanya diberikan kepada Ashabah. Menurut Hazairin. ${ }^{27}$ Ashabah dibagi tiga golongan yaitu:

1) Ashabah binafsihi;

2) Ashabah bilghairi;

3) Ashabah ma'alghairi.

3) Dalam garis ke samping:

Menurut M. Ali Hasan ashabah terdiri atas: ${ }^{28}$

1) Ashabah binafsihi yaitu ashabahashabah yang berhak mendapat semua harta atau semua sisa, yang urutannya sebagai berikut:

a) Anak laki-laki;

b) Cucu laki-laki dari anak lakilaki dan terus ke bawah asal saja pertaliannya masih terus laki-laki;

c) Ayah;

d) Kakek dari pihak ayah dan terus ke atas pertaliannya belum putus dari pihak ayah;

e) Saudara laki-laki sekandung;

f) Saudara laki-laki se-ayah;

g) Anak saudara laki-laki sekandung;

h) Anak saudara laki-laki seayah;

i) Paman yang sekandung dengan ayah;

j) Paman yang se-ayah dengan ayah;

k) Anak laki-laki paman yang sekandung dengan ayah;

l) Anak lai-laki paman yang seayah dengan ayah.

2) Ashabah bilghairi yaitu ashabah dengan sebab orang lain, yakni seorang wanita yang menjadi ashabah karena ditarik oleh seorang laki-laki, mereka yag termasuk ashabah bilghairi ini adalah sebagai berikut:

a) Anak perempuan yang didampingi oleh anak laki-laki;

b) Saudara perempuan yang didampingi oleh saudra lakilaki. 
3) Ashabah ma'al ghairi yakni saudara perempuan yang mewaris bersama keturunan dari pewaris, mereka itu adalah:
a) Saudara
perempuan
sekandung, dan
b) Saudara perempuan se-ayah

c. Ahli waris menurut garis ibu, disebut dzul arhaam. Arti dzul arhaam adalah, "orang yang mempunyai hubungan darah dengan pewaris melalui pihak wanita saja" Hazairin menyebutkan perincian mengenai dzul arhaam, yaitu: "semua orang yang bukan dzul faraa'idh dan bukan ashabah, yang umumnya terdiri atas orang yang termasuk anggota-anggota keluarga patrilinel pihak menantu laki-laki atau anggota-anggota keluarga pihak ayah dan ibu. ${ }^{29}$

Bagian masing-masing ahli waris dzul faraa'idh, di antara ahli waris yang ditentukan bagiannya di dalam Al-Qur'an hanya ahli waris dzul faraa'idh, bagian mereka selamanya tetap tertentu dan tidak berubah-rubah. Berbeda dengan para ahli waris ash shabah dan dzul arham. Bagian mereka sisa setelah dikeluarkan hak para ahli waris dzul faraa'id. Bagian ahli waris dzul faraa'idh adalah sebagai berikut:

a. Mendapat $1 / 2$ dari harta peninggalan terdapat lima golongan yaitu:

1) Seorang anak perempuan bila tidak ada anak laki-laki. (Al-Qur'an, surat An-Nisa: 11). Seorang anak perempuan (dari anak laki-laki) bila tidak ada cucu laki-laki.
2) Seorang saudara perempuan kandung, bila tidak ada saudara laki-laki (Al-Qur'an, surat An-Nisa: 176).

3) Seorang saudara perempuan seayah, bila tidak ada saudara laki-laki (Al-Qur'an, surat An-Nisa: 176).

4) Suami bila isteri yang meninggal tidak meninggalkan anak atau cucu (Al-Qur'an, surat An-Nisa: 12)

b. Yang mendapat $1 / 4$ bagian dari harta peninggalan terdapat dua golongan:

1) Suami bila isteri yang meninggal mempunyai anak atau cucu (AlQur'an, surat An-Nisa: 12)

2) Isteri bila suami yang meninggal tidak meninggalkan anak atau cucu (Al-Qur'an, surat An-Nisa: 12)

c. Ahli waris yang mendapat dari harta peninggalan hanya satu golongan yaitu: Isteri bila suami yang meninggal dengan meninggalkan anak atau cucu (Al-Qur'an, surat An-Nisa: 12)

d. Ahli waris yang mendapat $1 / 8$ bagian dari harta peninggalan, hanya isteri (zaujah) $^{30}$ baik seorang ataupun lebih, Ahli waris yang mendapat 1/6 bagian dari harta peninggalan ada dua golongan yaitu:

1) Ibu bila yang meninggal tidak ada anak atau cucu atau dua orang saudara atau lebih (Al-Qur'an, surat An-Nisa: 11). 
2) Dua orang atau lebih saudara seibu baik laki-laki maupun perempuan, dengan pembagian yang sama.

e. Ahli waris yang memperoleh $2 / 3$ bagian dari harta peninggalan terdapat 4 (empat) golongan:

1) Dua orang atau lebih anak perempuan, bila tidak ada anak laki-laki (Al-Qur'an, surat An-Nisa: 11);

2) Dua orang cucu perempuan atau lebih dari anak laki-laki bila tidak ada cucu laki-laki, anak perempuan;

3) Dua orang saudara perempuan kandung atau lebih bila tidak ada saudara laki-laki (Al-Qur'an, surat An-Nisa: 176);

4) Dua orang saudara perempuan seayah atau lebih bila tidak ada saudara laki-laki (Al-Qur'an, surat An-Nisa: 176).

f. Para ahli waris yang meninggal memperoleh 1/6 Dari harta peninggalan terdapat tujuh golongan yaitu:

1) Ibu jika yang meninggal dunia meninggalkan anak atau cucu (AlQur'an, surat An-Nisa: 11)

2) Ayah jika yang meninggal dunia mempunyai anak atau cucu (AlQur'an, surat An-Nisa: 11)

3) Nenek ibu dai ibu bapak

4) Seorang cucu perempuan dari anak laki-laki bersamaan dengan anak perempuan (HR. Buchori)

5) Kakek bapak dari bapak bersamaan dengan anak cucu bila ayah tidak ada.
6) Seorang saudara ibu, laki-laki atau perempuan (Al-Qur'an, Surat AnNisa: 12).

7) Saudara perempuan, seorang atau lebih bersamaan dengan saudara kandung.

Eman Suparman, ${ }^{31}$ menyebutkan mengenai keutamaan ahli waris atau ahli waris pengganti menurut Al-Qur'an adalah, dalam sistem hukum waris Islam menurut Al-Qur'an yang merupakan sistem waris bilateral, dikenal adanya ahli waris dzul faraa'idh yang bagiannya tetap, tertentu serta tidak berubah-rubah, juga terdapat, juga terdapat ahli waris ashabah dan ahli waris dzul arhaam. Kedua macam ahli waris atau ahli pengganti tersebut memperoleh bagian sisa dari harta peninggalan setelah dikurangi hutanghutang pewaris termasuk ongkos-ongkos biaya kematian, wasiat, dan bagian para ahli waris dzul faraa'idh, di samping itu dikenal juga ahli waris yang didahulukan unuk mewaris dari kelompok ahli waris lainnya yang disebut dengan kelompok keutamaan yang terdiri dari:

a. Keutamaan pertama yaitu:

1) Anak, baik laki-laki maupun perempuan, atau ahli waris pengganti kedudukan anak yang meninggal dunia;

2) Ayah, ibu, dan duda atau janda. Bila tidak terdapat anak.

b. Keutamaan kedua yaitu:

1) Saudara, baik laki-laki maupun perempuan, atau ahli waris pengganti kedudukan saudara;

2) Ayah, ibu dan janda atau duda, bila tidak ada saudara. 
c. Keutamaan ketiga yaitu:

1) Ibu dan ayah bila ada keluarga, ibu dan ayah bila salah satu, bila tidak ada anak dan tidak ada saudara;

2) Janda dan duda.

d. Keutamaan keempat yaitu:

1) Janda dan duda;

2) Ahli waris pengganti kedudukan ibu dan ahli waris pengganti ayah. $^{32}$

Mengenai pembagian kewarisan Islam ini berdasarkan Al-Qur'an adalah pedoman ijtihad para ulama, seperti halnya di Indonesia, ijtihad disusun menjadi peraturan yang dihimpun dalam kompilasi hukum Islam dikuatkan dengan suatu instruksi Presiden Nomor 1 Tahun 1991. ${ }^{33}$ Sebagaimana menurut Ismail Sunny, bahwa dalam bidang hukum perkawinan, hukum kewarisan, dan hukum wakaf bagi pemeluk-pemeluk Islam yang ditetapkan undang-undang yang berlaku adalah hukum Islam, maka Kompilasi hukum Islam yang memuat hukum matriilnya dapat ditetapkan oleh Keputusan Presiden atau Instruksi presiden. ${ }^{34}$

\section{Teori Maslahah Mursalah yaitu teori} hukum Islam yang selaras dengan tujuan hukum Islam yang menitik beratkan kepada tiga hal: pertama, lebih mengutamakan kemaslahatan dibanding kemadhorotan, kedua, prinsif tujuan hukum Islam bersifat memelihara Din, jiwa, akal, keturunan, harta, dan ummat. Kemudian yang ketiga, bahwa tujuan hukum Islam berkaitan dengan eksistensi pembuat hukum yang maha tinggi dan adanya manusia sebagai pelaksana hukum. Dalam Al-Maslahah Al-Mursalah menurut para ahli ushul memberikan takrif al-maslahah al-mursalah dengan "memberikan hukum syara kepada sesuatu kasus yang tidak terdapat dalam nash atau ijma atas dasar memelihara kemaslahatan. ${ }^{35}$

Mengenai kemaslahatan ini menurut

A. Djazuli, ${ }^{36}$ ada tiga macam yaitu:

1. Kemaslahatan yang ditegaskan oleh Al-Qur'an atau As-Sunnah, hal ini disepakati para ulama, contohnya seperti hifdzu nafsi, hifdzu mal dan lainnya.

2. Kemaslahatan yang bertentangan dengan nash syara yang qoth'i namun jumhur ulama menolak kemaslahatan ini kecuali Najmudin Athifi dari mazhab Maliki.

3. Kemaslahatan yang tidak dinyatakan oleh syara, tapi tidak ada dalil yang menolaknya, inilah yang dimaksud dengan Al-Mursalah. Namun bentuk ini tidak semua ulama dapat menerimanya.

Kegunaan Al-Maslahah Al-Mursalah adalah diperlukan untuk kehati-hatian sebab jika tidak akan mengakibatkan

32 Pasal 185Kompilasi Hukum Islam, mengenai ahli waris pengganti

33 Abdurahman, Kompilasi Hukum Islam di Indonesia, Penerbit Akademika Pressindo, Jakarta, 1992, hlm. 53.

35 A. Djazuli, Ilmu Fiqh, Penggalian, Perkembangan, dan Penerapan Hukum Islam, Prenada Media, Jakarta, 2005, hlm. 86 
cenderung mengikuti hawa nafsu belaka, karenanya diperlukan syarat-syarat tertentu maslahah mursalah seperti: Menurut Abd. Al-Wahab khalaf, ${ }^{37}$ dan Abu Zahrah, ${ }^{38}$ persyaratan-persyaratan tersebut adalah:

1. Al-Masalahah Al-mursalah tidak bertentangan dengan Mmuqashid alSyari'ah, dalil-dalil kulli semangat ajaran Islam dan dalil-dalil juz'i yang qath'i wurudl dan dalalahnya.

2. Kemaslahatan tersebut harus meyakinkan, dalam arti harus pembahasan dan penelitian yang rasional serta mendalam, sehingga yakin akan memberikan manfaat atau menolak kemadharatan.

3. Kemaslahatan tersebut bersifat umum.

4. Pelaksanaannya tidak menimbulkan kesulitan yang wajar.

Dari persyaratan tersebut, terjadi dalam kewarisan, hal ini tampak pada pembagian waris, dengan cara yang maslahat atau bahkan madharat, tergantung pada para ahli waris dalam menyikapinya. Perkembangan Hukum Waris Islam di Indonesia merupakan salah satu sistem hukum dari tiga sistem, dua sistem yang lainnya adalah hukum Adat dan hukum Barat. Perkembangan hukum Islam dan hukum waris Islam tidak lepas dari terdapatnya masyarakat muslim, dan pada diri seorang muslim ada suatu kewajiban harus taat terhadap hukum Islam, yaitu taat pada Allah SWT dan Rasul-Nya. ${ }^{39}$ karenanya saat ia memeluk agama Islam otomatis hukum Islam berlaku padanya. ${ }^{40}$ Di Indonesia Eksistensi dan penegakan hukum Islam mendapat jaminan dari peraturan perundang-undangan seperti terdapat dalam Piagam Jakarta 22 Juni 1945 yang menjiwai Undang-Undang Dasar $1945^{41}$ Secara Konstitusional pasal 29 (1) dan (2) Undang-Undang 1945 merupakan pengakuan eksistensi hukum Islam di Indonesia menyebutkan sebagai berikut:

1. Negara berlandaskan Ketuhanan Yang Maha Esa.

2. Negara Menjamin kemerdekaan tiap-tiap penduduk untuk memeluk agamanya masing-masing dan untuk beribadat menurut agamanya dan kepercayaannya itu.

Ketuhanan Yang Maha Esa menjadi dasar Negara adalah merupakan sila pertama dan Pancasila ${ }^{42}$ Ketuhanan Yang Maha Esa juga menjiwai sila-sila yang lainnya. Dari susunan hirarki dan pyramidal Ketuhanan Yang Maha Esa

37 Abd. Wahab Khalaf, Ilmu Ushul al-Fiqh, al-dar al-kawaetiyah, Mesir, Cetakan 8, 1968, hlm. 32-33.

38 Abu Zahrah, Al-ahwal, al Syakhsyiayh, Dar al-Fikri al-Arobi, Mesir, 1957, hlm.19.

39 Lihat Al-Qur'an(4):59

40 Hal itu disebut dengan teori penaatan Hukum, lihat artikel Ictiyanto, dalam Juhaya, S.P. Ed. Hukum Islam di Indonesia Dalam Perkembangan Dan Pembentukannya, PT, Remaja, Rosdakarya, Bandung, 1991, hlm. 100.

41 Endang S. Anshori, Piagam Jakarta 22 Juni 1`945 Dan Sejarah Konsensus Nasional Antara Nasionalis Islam Dan Nasionalis "Sekuler" Tentang daasr Negara Repubblik Indonesia, 1945-1959, Bandung, Pustaka, 1983, hal. 101.

42 Pasal 1 Ayat (3) Ketetapan MPR RI No.III/MPR/2000 tentang Sumber Hukum Dan Tata Urutan Peraturan Perundang-Undangan menentukan bahwa sumber hukum dasar nasional adalah Pancasila sebagaimana yang tertulis dalam Pembukaan UUD’45. 
menjadi basis sila-sila lainnya Pancasila ${ }^{43}$. Hazairin menafsirkan Pasal 29 Ayat (1) Undang-Undang dasr 1945 dengan beberapa kemungkinan: ${ }^{44}$

1. Dalam negara Republik Indonesia tidak boleh terjadi atau berlaku kaidah-kaidah Islam bagi umat Islam atau bertentangan dengan agama Nasrani bagi umat Nasrani atau yang berentangan dengan agama Hindu Bali bagi yang beragama Hindu bali atau yang bertentangan dengan kesulilaan agama Budha bagi yang beragam Budha.

2. Negara Repulik Indonesia wajib menjalankan syariat Islam bagi yang beragam Islam, juga syariat bagi yang beragama yang lainnya sesuai dengan keyakinan agamanya.

3. Dan Syariat yang tidak memerlukan bantuan Negarauntukmenjalankannya dan karena itu dapat berdiri sendiri dijalankan oleh setiap pemeluk agama yang bersangkutan menjadi kewajiban pribadi terhadap Allah SWT dan menurut agamanya masing-masing.

Hukum Islam yang berlaku bagi masyarakat muslim Indonesia ada yang bersifat normatif dan sebagian ada yang telah menjadi hukum positif, diantaranya yang telah menjadi hukum positif adalah hukum waris yang telah mendapat pengakuan negara dengan jaminannya instruksi Presiden Republik Indonesia. Waris merupakan perilaku pengabdian terhadap Allah SWT dan merupakan suatu wadah dalam kehidupan masyarakat yang dapat menjadi alternatif untuk pembinaan kesejahteraan keluarga, Al-Qur'an surat An-Nahl (16): 71 menerangkan "Dan Allah melebihkan sebagian kamu dari sebagian yang lain dalam hal rezeki".

Mengenai ketentuan waris hukum Islam bagian waris anak perempuan mendapat setengah dari bagian anak laki-laki, dalam surat An-Nisa: 11 yaitu Apabila hanya ada anak perempuan, maka ia memperoleh seperdua bagian. Apabila ada dua anak perempuan atau lebih, maka mereka memperoleh dua pertiga bagian. ${ }^{45}$ Apabila anak perempuan mewarisi sebagai asabah (asabah bilghairi). Ketentuan bagian warisan anak perempuan sebagai setengah bagian anak laki-laki. Kedudukan anak perempuan sebagai ahli waris pada dasarnya tergolong dalam dzawul faraidh, yang hak warisnya telah ditentukan dalam bilangan tertentu menurut $\mathrm{Al}$ Qur'an. ${ }^{46}$ tetapi kalau anak perempuan itu bersama anak laki-laki, maka ikut menjadi ashabah biroghairi ikut menghabiskan harta warisan sehingga ia mendapatkan $1 / 3$ bagian. Jika ahli waris seorang anak perempuan saja tanpa anak laki-laki, maka ia mendapatkan separo. ${ }^{47}$ Tetapi jika ahli waris itu beberapa anak perempuan dan tidak ada lelaki, maka anak perempuan mendapat 2/3 bagian yang dibagi mereka secara merata. ${ }^{48}$ Jika ada anak perempuan dan beberapa anak lelaki, sedangkan para 
ahli waris yang lain tidak ada. Maka setiap anak perempuan mendapat separo bagian dari anak laki-laki. Jadi setiap anak lakilaki mendapat 2 (dua) bagian sedangkan setiap anak perempuan mendapat satu bagian. Jika disamping ahli waris anak perempuan, ada anak laki-laki dan ada pula ahli waris yang lain, maka para ahli waris yang lain diberikan bagian yang lebih dulu, baru kemudian sisanya diberikan pada anak laki-laki dan anak perempuan. ${ }^{49}$ ringkasnya sebagai berikut:

1. Jika ahli waris wanita tunggal, mendapat separo bagian.

2. Jika ahli waris beberapa anak wanita tanpa ahli waris, maka anak-anak wanita mendapat 2/3 bagian.

3. Jika ahli waris ada beberapa wanita dan beberapa pria tanpa ahli waris yang lain, maka setiap wanita mendapat 1 bagian dan ahli waris pria mendapat 2 bagian.

4. Jika ahli waris wanita dan ahli waris pria bersama ahli waris lainya, maka setiap ahli waris wanita mendapat 1 bagian dan ahli waris pria mendapat 2 bagian. Karena itu jika ada ahli waris perempuan, maka yang terhalang adalah saudara seibu dengan pewaris yang tidak mendapat bagian. Begitu juga jika ada dua orang atau lebih ahli waris perempuan, maka yang terhalang tidak mendapat bagian adalah cucu dari anak perempuan, kecuali selain cucu perempuan itu ada cucu laki-laki, maka para cucu tersebut menjadi ashabah. Berbeda dari ahli waris anak laki-laki, maka ahli waris anak perempuan tidak menghalangi ahli waris yang lain, hanya saja karena adanya bagian bagi anak perempuan maka bagian untuk bapak dan ibu menjadi berkurang. Ketentuan yang mengatur pembagian waris terhadap anak perempuan menurut hukum Islam, yaitu terdapat dalam surat AnNisa: 11 disebutkan:

Apabila hanya ada anak perempuan, maka ia memperoleh seperdua bagian Apabila ada dua anak perempuan atau lebih, maka mereka memperoleh dua pertiga bagian. Apabila anak perempuan mewarisi sebagai ashabah (ashabah bighairi). Tetapi pembagian anak perempuan dengan anak lakilaki bisa:

1. Hadis Rasulullah Saw.

Riwayat Bukhori: tentang pembagian seorang anak perempuan, cucu perempuan dari anak lakilaki, dan saudara perempuan, Rasulullah menetapkan: untuk anak perempuan seperdua, cucu perempuan dua pertiga, dan selebihnya untuk saudara perempuan.

Riwayat Bukhori-Muslim, mengenai seorang nenek yang meminta hak waris karena pewaris adalah cucunya, dan sahabat Abu Bakar, memberi dengan seperenam kepada nenek tersebut.

Riwayat Bukhori dan iman yang lainnya, mengenai perintah Rasululloh Saw, bahwa jangan meninggalkan keturunan dalam keadaan miskin. 
2. Instruksi Presiden Republik Indonesia

Selanjutnya Instruksi Presiden Republik Indonesia No. 1 Tahun 1991 tentang Kompilasi Hukum Islam Buku II tentang Hukum Kewarisan. Misalnya: Kedudukan anak perempuan dalam Pasal 176 KHI yaitu:

"Anak perempuan bila hanya seorang ia mendapatkan separoh bagian, bila dua orang atau lebih mereka bersama-sama mendapat dua pertiga bagian, dan bila anak perempuan bersama-sama anak laki-laki, maka bagian anak lakilaki adalah dua berbanding satu dengan anak perempuan"

Seperti yang terdapat dalam Pasal 183 KHI yaitu:

"Paraahliwaris bersepakatmelakukan perdamaian dalam pembagian harta warisan, setelah masingmasing menyadari bagiannya".

Pasal tersebut merupakan bentuk kebijakan hukum Islam dengan memperhitungkan kemaslahatnnya, memberikan hak waris secara seimbang tanpa membedakan antara yang kecil dan besar, laki-laki atau pun perempuan, begitu juga dengan ahli waris pengganti, yang sudah jelas haknya. Hal ini Sesuai dengan teori Al-maslahah Al-Mursalah, yaitu suatu teori yang memberikan hukum syara kepada sesuatu kasus yang tidak terdapat dalam nash atau ijma, atas dasar memelihara kemaslahatan. ${ }^{50}$ Meskipun demikian almursalah memerlukan persyaratan agar terhindar dari sifat nafsu belaka . ${ }^{51}$ Dan tetap dalam nilai-nilai syari'ah. Imam AsSyatibi, yang dipertegas oleh Abd. Wahab Khallaf seta Abu Zahrah, ${ }^{52}$ memberikan persyaratan-persyaratan al-maslahah almursalah yaitu: ${ }^{53}$

Al-masalahah al-mursalah tidak boleh bertentangan dengan maqhoshid alsyari'ah, dalil-dalil kulli, semangat ajaran Islam dan dalil-dalil juzi'i yang qoth'i dan dalalahnya. Kemaslahatan tersebut harus meyakinkan dalam arti harus ada pembahasan dan penelitian yang rasional serta mendalam sehingga yakin hal tersebut memberikan manfaat atau menolak kemafsadatan.

Kemaslahatan bersifat umum Kemas-lahatan tidak menimbulkan kesulitan yang tidak wajar. Al-Maslahah al-mursalah sebagai cara berijtihad mempunyai kekuatan yang mementingkan kenyamanan terhadap semua pihak. Dengan menggunakan teori ini dapat dipahami bahwa prinsip hukum dua berbanding satu dalam pembagian waris anak perempuan dan anak laki-laki, adanya suatu perintah yang tersembunyi mengenai kemanfaatan perundingan keluarga, hal ini melatih tingkat ketaatan terhadap hukum dengan dibarengi kesadaran dan kesabaran hukum.

\footnotetext{
50 Sajuti Thalib, Hukum Kewarisan Islam di Indfonesia, Bina Aksara, Jakarta, 1984 ,hlm.56.

51 Ibid

52 Ketiga nama tersebut adalah pakar hukum Islam, penggerak pembaharuan hukum Islam di Timur Tengah dengam gagasan-gagasan hukum Islam yang aktual sampai kini.

53 Abdul Wahb Khalaf, As-Siyasah,Asy-Syari'ah: Dar al-Anshar, Kauro, 1977, hlm. 86-87.
} 
Teori Al-maslahah al-mursalah, dalam aplikasinya sejalan dengan kebjiaksanaan hukum Islam yang di kemukakan Ictyanto yaitu: ${ }^{54}$ kebijaksanaan tasryrik dan kebjaksanaan taklif. Kebijaksanaan tasyrik menyangkut pengundangan suatu aturan hukum Allahdan Rasul sesuai dengan situasi dan kondisi masyarakat. Kalau masyarakat belum matang untuk menerima Islam suatu ketentuan hukum, maka di buat suatu ketentuan hukum yang ringan. Kalau masyarakat telah menerima hukum Islam dengan kesadaran, maka ditingkatkan ketentuan hukum yang sesuai dengan hakikat manusia. Sebagai contoh: mengenai hukum larangan minuman keras, wahyu pertama mengatakan bahwa kers itu ada manfaatnya, dan ada dosanya (madhorotnya) namun dosanya lebih besar (QS. 2:219). Kemudahan setelah kesadaran hukum para shahabat meningkat, turun wahyu yang kedua yang berisi ketentuan bahwa kalau mengerjakan shalat jangan minum-minuman keras. (QS. 4:43Wahyu yang ketiga turun setalah kesadaran hukum para shabat cukup tinggi, dikatakan bahwa berjiudi minum-minuman keras adalah haram. (QS.5:90-91).

Kebijaksanaan taklif mengenai suatu kebijakan hukum Islam dalam penerapan suatu ketentuan hukum terhadap manusia sebagai mukallaf, (subjek hukum) dengan melihat siatuasi dan kondisi pribadi manusia itu, yaitu melihat kepada kemampuan fisik dan rohani(sudah dewasa),mempunyai kebebasan dan akal sehat, disamping mempunyai kondisi pribadi yang sangat khusus ada padanya. Oleh karena itu dalam kebijaksanaan taklif, hukum suatu perbuatan bagi seseorang dapat berbeda dengan hukum perbuatan itu bagi orang lain. Contohnya mencuri, ketentuan hukum mengatakan bahwa pencuri peempuan atau laki-laki dipotong tangannya, (QS.5:38). ${ }^{55}$ tetapi zaman Umar Bin Khaththab, potong tangan tidak dilaksanakan, karena melihat situasi dan kondisinya, yaitu melakukan pencurian karena kelaparan, dan situasinya kemiskinan.

Dua kebjikasanaan tersebut dalam hukum waris, dikembangkan untuk tujuan kemaslahaan hukum, dan hal ini sesuai dengan tujuan Islam yang dikembangkan oleh Imam al-Syatibi, ${ }^{56}$ bahwa tujuan hukum Islam adalah (maqashid alsyari'ah), dikenal dengan lima hal atau almaqashid al-khamsah yaitu: ${ }^{57}$

1. Memelihara agama (Hifdz al-Din) yang dimaksud agama, adalah dalam arti sempit atau ibadah makhdoh, ${ }^{58}$ suatu hubungan manusia dengan

54 Ictijanto, Pengembangan Teori Berlakunya Hukum Islam di Indonesia, Makalah, Bandung, 1991, Ictijanto adalah Dosen Capita Selekta Hukum Islam, dan Sejarah Hukum Islam pada fakultas Pascasarjana Universitas Indonesia, dan Dosen hukum adat di IAIN Syarif Hidayahtullah Jakarta,Pernah menjadi peneliti Badan Litbang Depag.

55 Lihat Al-Qur'an, surat Al-Maidah :38

56 Imam al-Syatibi, ulama besar bidang hukum Islam yang melakukan istiqro/penelitian hukum Islam dari Al-Qur'an dan Hadis.

57 A. Djazuli, Ilmu Ush Fiqh, Penggalian, Perkembangan, dan Penerapan Hukum Islam, Edisi Revisi, Prenada Media, Jakarta, 2005, hlm. 27.

58 Ibadah makhdoh adalah, suatu peribadahan khusus hukumnyawajib bagi setiap muslim yang baligh, yang tata cara pelaksanaannya tertertu dan ditentukan, tidak dapat di ubah, tetapi terdapat rukhshoh dalam keadaan dharurat. 
Allah SWT, di dalamnya ada aturan hukum mengenai hubungan manusia dengan Allah SWT, dan larangan yang meningggalkannya.

2. Memelihara diri (Hifdz al-Nafs), menjaga diri dari perbuatan yang merugikan diri dan orang lain, hukumnya adalah wajib.

3. Memelihara dan kehormatan keturunan (Hifdz al-nas/irdl) seperti aturan-aturan tentang pernikahan, larangan perzinahan, dan mengutamkan musyawarah.

4. Memelihara harta (Hifdz al-mal) termasuk didalamnya larangan untuk mencuri dan menghasab harta orang lain.

5. Memelihara akal(Hifdz al-Aql), termasuk didalamnya memelihara untuk tidk minum-minuman yang memabukan/minuman keras serta kewajiban untuk menuntut ilmu.

6. Lima hal tersebut ditambahkan oleh A. Djazuli. ${ }^{59}$ bahwa harus ada sifat memelihara umat (Hifdz al-ummah) yaitu menjaga kerukunan hidup berkeluarga dan bermasyarakat, sebab hal ini merupakan ujung tombak penegakan hukum waris Islam di Indonesia.

Berkaitan dengan kedudukan ahli waris pengganti adalah sah hal lumrah atau sepantasnya menurtut para ulama, dalam penegakan hukumya, karena ada pintupintuijtihad yang memberikan solusi tanpa harus melanggar aturan Al-Qur'an. Hal itu dilihat dari segi kehidupan akan membawa suatu kemaslahatan, baik kemaslahatan dari segi pengaruhnya atas kehidupan umat manusia, dalam ikatan keluarga dan persaudaraan atau kemaslahatan dari segi hubungannya dengan kepentingan umum dan individu dalam masyarakat, dan atau bahkan kemaslahatan yang bersifat universal dan menyangkut kepentingan kolektif (kulliyah) dan kemaslahatan yang menyangkut kepentingan individual (farduyyah), hal tersebut didasarkan kepada suatu prinsip umum hukum Islam, yaitu bahwa semua manusia beada dalam suatu ketetapan yang sama, yaitu ketetapan Tauhid yang dinyatakan dalam kalimat Laa "ila'ha Illal lah, (tiada Tuhan selain Alloh SWT). ${ }^{60}$

Berdasarkan atas prinsip tauhid ini, makapelaksanaanhukumIslammerupakan ibadah, ibadah dalam arti penghambaan manusia dan penyerahan dirinya kepada Allah SWT sebagai manifestasi pengakuan atas ke-Mahaesaan-Nya dan manifestasi kesyukuran kepada-Nya. Prinsip ini menghendaki dan mengharuskan manusia untuk menetapkan hukum sesuai dengan apa yang diturunkan Allah SWT yaitu AlQur'an, hal ini jika dilihat dari illat hukum Islam yang berarti hikmah, atau manfaat yang nayta atau menolak kekerasan, maka berkaitan dengan kaidah hukum:

Yagh yiirul ahkami bitghoirul aj' minati wal al am kinati wal ni yaati wal ghowaa i'di

\footnotetext{
$59 \quad$ A. Djazuli, Pakar Hukum Islam adalah Guru Besar bidang ilmu Ilmu Ush Fiqh dan Ilmu Fiqh serta di UIN Bandung. Menyatakan hal tersebut dalam Pidato pengukuhan Guru Besar Hukum Islam Tahun 1996, dan hal itu ditegaskan kembali dalam penganugerahan Doktor Honorius Causa pada Tahun 2009 dalam sidang terbuka di Kampus UIN Bandung.

60 Juhaya S. Praja, Op.Cit., hlm. 69.
} 
"Perubahan hukum itu terjadi karena perubahan waktu dan ruang, nia serta manfaat".

\section{PENUTUP}

1. Kedudukan ahli waris pengganti dalam hukum Islam Hukum Islam berlandaskan pada Pasal 185 Kompilasi Hukum Islam di Indonsia dengan berpegang pada prinsip tauhid, suatu ketaatan pada aturan Tuhan dengan tetap jangan melupakan Iltihad karena ijtihad merupakan salah satu disebut dalam Al-Qur'an surat dalam An-Nisa:(59). Mengenai kemestian ketataatan pada hukum Tuhan tidak boleh saling mengtuhankan sesama manusia dan atau sesama makhluk lainnya termasuk mengtuhankan harta, namun diwajibkan memelihara harta, menjaga hubungan baik dalam dalam pembagian harta warisan. Dan hubungannya dengan prinsip keadilan dalam hukum Islam terdapat dalam rangka mendapatkan keadilan dengan penuh hikmah, serta mengandung aspek manfaat, atau keamaslahatan sesuai dengan kaidah hukum (fqh) bahwa : "Perubahan hukum itu terjadi karena perubahan waktu ruang, niat serta manfaat" dan menjadi tangggung jawab negara untuk mengaturnya, dalam realisasinya negara sudah mengatur dengan hadirnya KHI. bagiannya".

2. Prinsif Tauhid merupakan dasar bagi teori Al-Maslahah Al-Mursalah yaitu, mencari manfaat karena Allah SWT. seperti yang dikemukakan Al-Ghazali juga para ulama lainnya, terdapat manfaat yang tercakup dalam tujuan syara, jadi mengenai pembagian waris dua berbanding satu dapat dicapai mana lebih mengutamakan kemaslahatan dibanding kemadhoratan dalam kehidupan keluarga dan al-arham (silaturahmi), hukum Al-Qur'an tidak kaku. AlMaslahah al-mursalah sebagai cara berijtihad mempunyai kekuatan yang mementingkan kenyamanan terhadap semua pihak.

\section{DAFTAR PUSTAKA}

A. Djazuli, Ilmu Fiqh, Penggalian, Perkembangan, dan Penerapan Hukum Islam, Prenada Media, Jakarta, 2005.

Ali Hasan, Hukum Warisan Dalam Islam, Bulan Bintang, Jakarta, 1990.

Abdurahman, Kompilasi Hukum Islam di Indonesia, Penerbit Akademika Pressindo, Jakarta, 1992.

Abd.Wahab Khalaf, Ilmu Ushul al-Fiqh,aldar al-kawaetiyah, Cetakan 8, Mesir, 1968.

Abu Zahrah, Al-ahwal, al Syakhsyiayh, Dar al-Fikri al-Arobi, Mesir, 1957,

Eman Suparman, Intisari Hukum Waris Indonesia, Armico Bandung, 1985,

Endang S. Anshori, Piagam Jakarta 22 Juni 1945 Dan Sejarah Konsensus Nasional Antara Nasionalis Islam Dan Nasionalis "Sekuler" Tentang Dasar Negara Repubblik Indonesia, 19451959, Pustaka, Bandung, 1983. 
Hazairin, Hukum Kewarisan Islam menuru Al-Qur'an, Jakarta, TT.

Demokrasi Pancasila, Reneka Cipta, Jakarta, 1990.

Ictijanto, Pengembangan Teori Berlakunya Hukum Islam di Indonesia, Makalah, Bandung, 1991.

Juhaya S. Praja, Hukum Islam di Indonesia, PT. Remaja Rosdakarya, Bandung, 1991.

, Filsafat Hukum Islam, Fakultas Syari'ah, IAILM, Tasikmalaya, 2004.

Mohammad Daud Ali, Pengantar Ilmu Hukum dan TataHukum Islam di Indonesia, Jakarta, Raja Garifindo Persada, 1990.

Muhammad Alias-Shabana, Hukum Waris Dalam Syariat Islam, Cv. Dipenegoro, Bandung, 1988.

M. Idris Ramulyo, "Suatu Perbandingan Antara Ajaran Syafi'i dan Wasiat Wajib di Mesir, Tentang Pembagian Harta Warisan Untuk Cucu Menurut Islam" Majalah Hukum Dan Pembangunan No. 2 Thn. XII Maret 1982, Jakarta, 1982.

Mayer, Robert R.and Greenwood, Ernest, The Design of Social Policy (Rancangan Penelitian Kebijakan Sosial), Terjemahan Sutan Zanti Arbi dan Wayan Ardhana, Pustekom Dikbud dan Rajawali, Jakarta, 1984.
Moh. Nazir, Metode Penelitian, Ghalia Indonesia, Jakarta, 2003.

Notonagoro, Pancasila Dasar Negara, Bina Aksara, Jakarta, 1988.

Rachmad Budiono, Pembaruan Hukum Kewarisam Islam Di Indonesia, Bandung, 1999.

Retno Sutantio, Wanita dan Hukum, Alumni, Bandung, 1979.

Soejono Soekanto, Pengantar Penelitian Hukum, UI Press, Jakarta, 1986.

Sajuti Thaqlib, Hukum Kewarisan Islam di Indonesia, Bina Aksara Jakarta, 1964.

Satrio. J, Hukum Waris, Citra Aditya Bakti, Bandung, 1990.

Subekti, Pokok-pokok Hukum Perdata, Intermasa Jakarta, 1985.

Sudarsono, Hukum Kekeluargaan Nasional, Rineka Cipta Jakarta, 1991.

Suhrawardi, dan Komis Simanjuntak, Hukum Waris Islam Hukum Waris Islam, Sinar Grafika, Jakarta, 2000.

Sulaiman Rasjid, FiqhI slam, Penerbit Attahiryah, Cetakan ketujuh belas, Jakarta, 1976.

Shohibul Munir, Ilmu faraidh, PT. Al-Maarif, Cetakan Kedua, Bandung, 1984.

Ter Haar Bzn. Mr., Terjemahan K.Ng. Soebakti Poeponoto, Asas-asas dan 
Susunan Hukum Adat, Pradnya

Paramita, Cetakan IX, Jakarta, 1987.

Toto Suryana, dkk, Pendidikan Agama Islam Untuk Perguruan Tinggi, Tiga Mutiara, Bandung, 2000.

Wirjono Prodjodikoro, Mr. Hukum Warisan di Indonesia, Bandung, Vorkink-van Hoeve.

\section{Sumber Lain:}

Al-Qur'an dan Terjemah, Departemen Agama Republik Indonesia, 2010.

Undang-Undang Dasar 1945.

Intruksi Presiden Indonesia Nomor 1 Tahun 1991 Tentang Kompilasi Hukum Islam. 